\title{
The Use of Chemical Weapons in Syria: Implications and Consequences
}

\author{
Ralf Trapp
}

\begin{abstract}
Chemical weapons are banned under customary international law, the 1925 Geneva Protocol and the 1997 Chemical Weapons Convention (CWC). The CWC today has achieved near universal adherence; a small number of states, however, remain outside its realm. Syria-until 2013 one of them-was long presumed to possess chemical weapons and in 2012 effectively admitted so. The Syrian civil war always carried the risk that one side or another would use these weapons. Reports to this end began to appear in 2012. In March 2013, following separate requests by Syria and several Western States, the UN Secretary-General began to investigate these allegations. Whilst the investigation team was in Damascus, a large-scale sarin attack was launched on Ghouta, killing hundreds of people. This incident and its subsequent confirmation by the UN team set in motion a series of unprecedented events leading to the elimination of Syria's chemical weapons stockpile under strict international control, supported by financial and in-kind assistance by more than 20 countries. But this multilateral effort did not end the use of toxic chemicals in Syria, and OPCW fact-finding missions have since confirmed several cases of chlorine attacks. Also, ISIS/Daesh reportedly has used chemical weapons including chlorine and mustard gas in Syria and Iraq. The paper concludes that it will be important to identify the perpetrators of these attacks and bring them to justice in order to protect the international norm against poison gas.
\end{abstract}

\section{Introduction}

On April 29, 1997, after two decades of negotiations in the Geneva Conference on Disarmament and another four years of work of the Preparatory Commission in The Hague, the Chemical Weapons Convention (CWC) entered into force. As of the

\footnotetext{
R. Trapp $(\bowtie)$

International Disarmament Consultant, Chessenaz, France

e-mail: ralf.trapp@gmail.com

(C) The Author(s) 2017

B. Friedrich et al. (eds.), One Hundred Years of Chemical Warfare: Research,

Deployment, Consequences, DOI 10.1007/978-3-319-51664-6_19
} 
summer of 2015, this global disarmament treaty, which aims at abolishing once and for all the threat of chemical warfare, had attracted 191 states as its parties. ${ }^{1}$ Near universal adherence to this comprehensive ban combines with efforts of the States Parties to internalize its prohibitions and set them firmly into their domestic legislation, penal codes and administrative and enforcement systems. The chemical weapons arsenals and production facilities of the vast majority of countries are under the control of the Convention's treaty organization - the Organization for the Prohibition of Chemical Weapons (OPCW) - and measures to eliminate them are nearing completion. An effective verification system with on-site inspections has been established to verify declarations by the States Parties, ensure that all declared chemical weapons and production facilities are being destroyed, and that no new chemical weapons are produced. To many observers, it appeared that the menace of chemical warfare had become a matter of the past.

But whilst chemical weapons were successfully being taken out of the armory of the majority of countries that had acquired them in the past, a small number of countries remained outside the realm of the CWC. ${ }^{2}$ Some of them are presumed to have chemical weapons in their arsenals. The dangers that emanate from the continuing presence of chemical weapons in military arsenals became apparent when Syria spiraled into civil war after the "Arab Spring".

\section{Early Reports of Chemical Weapons Use in the Syrian Civil War}

In July 2012, a spokesperson of the Syrian Foreign Ministry effectively admitted that Syria possessed chemical weapons; he went on to say that Syria would not use these weapons except against an external aggression (MacFarquhar and Schmitt 2012). Around the same time, reports appeared that claimed that terrorist groups were smuggling chemical weapons from Libya and other countries via Turkey into Syria. Beginning in late 2012, reports emerged on the Internet and in the media alleging the use of chemical weapons in Syria by government forces. At the same time, government sources in Syria claimed that terrorist groups were using improvised chemical weapons.

Whilst the Independent Commission of Inquiry into Syria of the UN Human Rights Council in February 2013 still concluded that there was no credible evidence for the use of chemical weapons by either side (UNGA 2013), allegations and counter-allegations of such uses were increasingly leveled against the Syrian government but also against certain factions of the military opposition, including elements of the Free Syrian Army and groups such as Jabhat al Nusra. Then, in

\footnotetext{
${ }^{1}$ For status updates, see http://www.opcw.org/about-opcw/member-states/status-of-participation/.

${ }^{2}$ As of October 2015, Israel — a signatory state — has yet to ratify its signature, and Egypt, South Sudan, and North Korea have yet to accede to the Convention.
} 
March of 2013, the UN Secretary-General received a request from the government of Syria to investigate an alleged chemical weapons attack against government troops and civilians in Khan $\mathrm{Al}$ Asal near Aleppo. ${ }^{3}$

According to the Syrian report, 25 people had died and more than 110 civilians and soldiers been injured as the result of an attack with what was said to have been a chemical rocket. The Syrian government accused the opposition of being responsible for the chemical attack whilst an opposition military spokesperson blamed government troops for it. Subsequently, France and the United Kingdom reported allegations of the use of chemical weapons in several locations in Syria, including in Khan Al Asal and near Damascus, Aleppo, and Homs, near the Turkish border, and in other places, blaming the Syrian regime as the instigator (UNODA 2013, 2). They requested that the UN investigation be mandated to investigate all these alleged incidents. The United States, who had initially been cautious about confirming any chemical weapons use by either side, eventually also concluded that the government of Syria had used chemical weapons in several instances (ibid., 3-4).

\section{The Secretary-General's Investigation}

In response to these requests, the UN Secretary-General established an investigation mission under the leadership of Swedish scientist Åke Sellström, using a mechanism that had been devised during the Cold War as a tool to investigate alleged breaches of the 1925 Geneva Protocol (Ban 2013a). The mission was composed of a group of inspectors of the OPCW, medical experts of the WHO, and supported by UN staff in New York as well as Syria and the region. But Sellström's team was for several months unable to go into Syria, whilst in New York negotiations continued behind closed doors about which specific incidents and locations the team would be allowed to scrutinize.

All along, however, video footage and photographic images spread through social media and the Internet, showing what appeared to be further victims of poison gas attacks. There also were reports from journalists who had managed to gain access to activists in Syria or who had in fact spent time with one or another group of fighters, and who had collected information about the alleged chemical weapons attacks. Several States extended their own intelligence gathering operations in Syria. Russia, France, the United Kingdom, and the United States all acquired samples from different sources and locations of alleged gas attacks, and analyzed them for the presence of chemical agents. They concurred that their analysis showed that the nerve agent sarin had been used. But whilst Russia concluded that terrorist groups fighting for the opposition had used the nerve agent,

\footnotetext{
${ }^{3}$ For a chronology of the allegations and the steps taken by Secretary-General and his investigation team, see the Final Investigation Report (UNODA 2013).
} 
Western countries concluded that it had been the Assad regime who was responsible for the gas attacks (Robinson 2013, 28-34; Gladstone 2013).

Any use of chemical weapons would, of course, constitute a war crime. Not only have chemical weapons been banned by the 1925 Geneva Protocol and the 1997 Chemical Weapons Convention, but there is also a common view that under customary international law, any use of a chemical weapon in armed conflict would constitute a prohibited act (ICRC 2005). Amongst the many atrocities committed in the Syrian civil war, and meticulously recorded by the Independent Commission of Inquiry into Syria of the Human Rights Council, the use of chemical weapons was specifically noted as an act that is prohibited in all circumstances under customary international humanitarian law, and a war crime under the Rome Statute (UNGA 2013).

But the situation remained unclear for some time. Sellström's investigation team could not get into Syria, and much of the information could not be independently verified. Videos and images posted on the Internet did not allow an unequivocal confirmation that sarin had in fact been used; the authenticity of the samples analyzed by the different countries could not be demonstrated independently; videos and photographs on the Internet appeared to show both Syrian army and opposition fighters preparing and firing what were described to be chemical rockets; and, unsurprisingly, the propaganda war surrounding the allegations and the debate about how the international community should respond increased in intensity, obscuring both the facts of the matter and the underlying intentions of the different actors involved. The stakes were high, framed by fears about possible military strikes on the one side and hopes for military intervention and support on the other.

After several months of negotiations between the UN and Syria about which particular locations the team would be allowed to access and investigate, the UN Secretary General's investigation mission was finally dispatched to Damascus in the middle of August 2013. Whilst the team was making final preparations for its fieldwork at its operations base in Damascus, in the night of August 21, 2013, a major gas attack was launched against civilian quarters in Ghouta, a suburb just outside of Damascus. Within hours, videos posted on the Internet showed large numbers of victims arriving in hospitals for treatment of what clearly were poison gas injuries, among them many women and children. The precise number of casualties has never been established and would be difficult if not impossible to verify-casualty figures ranged from 355 to more than 1500 people killed plus many more injured - but there was little doubt that a war gas had been used (France 2013; United States 2013).

What followed had no precedence in the history of chemical weapons disarmament. First, within days, despite the on-going civil war and in fact despite having been attacked by sniper fire on one occasion, the UN investigation team negotiated its way into the attacked sites and carried out as thorough an investigation as was possible under the conditions of the civil war. In the compressed time available, the team interviewed a significant number of victims of the attack, medically examined many of them and took blood samples for subsequent analysis. It also inspected several of the impact sites and conducted interviews with eye witnesses, assessed 
the remnants of the weapons used, estimated likely flight trajectories, and took samples from impact craters and from the weapons themselves (UN Mission 2013, p. 4 and appendices 5 and 6). Subsequent analysis of these biomedical and environmental samples undertaken by OPCW designated laboratories confirmed beyond doubt that sarin had been used, in significant amounts, in the attack on Ghouta.

The Sellström team subsequently also investigated other incidents of alleged chemical attacks in Syria and was able, with varying degrees of certainty, to confirm that sarin had been used in a number of cases (UNODA 2013, 19-21). The incidents for which the use of the nerve agent was confirmed included both scenarios where Syrian government forces were accused of having used chemical weapons and scenarios where the opposition had been accused of having done so. The UN team was not mandated, however, to establish which party had used the chemical weapon. In fact, such an attribution would have required a different type of investigation, and access rights as well as investigative tools reaching beyond what the team could bring to bear under the circumstances and the scope of the UN Secretary-General mechanism (for example, reference data with the precise analytical signatures of the chemical agent mixtures present in the Syrian CW stockpile and access to documents and individuals in the military command structures of the parties involved in the incidents).

\section{The Elimination of the Syrian Chemical Weapons Program}

As political pressure mounted after the confirmation of the use of sarin in Ghouta, and the risk of external military intervention increased, a second remarkable development took place: a last-minute agreement was reached in Geneva between the Russian Federation and the United States of America about a framework for the elimination of Syria's chemical weapons program (OPCW 2013a), combined with Syria's accession to the Chemical Weapons Convention on September 13, 2013 and its declaration that it would apply the Convention's norms and obligations immediately, even before becoming a State Party.

Within a mere two weeks, the OPCW Executive Council transferred this general framework agreement into detailed modalities for the disablement and destruction of the Syrian chemical weapons arsenal and production capacity (OPCW 2013b). ${ }^{4}$ On the very same day, resolution 2118 (2013) of the UN Security Council

\footnotetext{
${ }^{4}$ Syria joined the $\mathrm{CWC}$ after the expiration of the ten-year destruction period prescribed under Article IV(6) of the CWC for the complete elimination of CW stockpiles (which expired April 29, 2007). In such a situation, the OPCW Executive Council under Article IV(8) of the CWC establishes the destruction deadlines and related verification measures for the newcomer State Party. This enabled the conversion of the bilateral US-Russian framework into a legally binding undertaking under the CWC without a formal amendment of the CWC.
} 
harnessed this decision and added the strength of the UN Charter to this endeavor. ${ }^{5}$ Within days, OPCW inspectors began inspecting the Syrian chemical weapons facilities to confirm weapons and equipment inventories, advise Syria on how to apply the requirements of the CWC, and start preparations for the destruction and removal operations envisaged. In October, a Joint Mission of the United Nations and the OPCW was established to implement and supervise the chemical weapons disarmament of Syria, led by Sigrid Kaag.

Syria declared a total of $41 \mathrm{CW}$ stockpile and production facilities at 23 locations (OPCW 2013c). 18 of them were CW production facilities, 12 were storage facilities, and there were 8 mobile filling units and 3 other $\mathrm{CW}$-related facilities. The declared stockpile amounted to 1000 tons of category-1 chemicals (these are chemicals listed in Schedule 1 of the CWC and included the sarin key precursor DF, a key precursor for VX, and mustard gas). There also were some 290 tons of other chemicals that formed part of the CW stockpile, 1230 items of unfilled munitions, and 2 cylinders which the Syrian government claimed did not belong to it but might contain chemical agent.

By the beginning of November, the initial inspections of the Syrian chemical weapons stocks and production facilities had been completed (OPCW 2013c). Some sites could only be inspected by authenticated video links but these turned out to be empty. The vast majority of the declared stockpile and production locations were inspected by OPCW inspectors, and their inventories of weapons, materials, and specialized production and filling equipment verified and secured. The stationary and mobile production and mixing units were functionally disabled: they were physically damaged so that they could no longer be used for their intended purpose. That was important because the deployment system that the Syrian army had developed for its main chemical weapon - the nerve agent sarin - depended on mixing two precursor materials (DF and iso-Propanol) and an acid scavenger (hexamethylene tetramine) to form sarin shortly before the weapons were deployed and used. Once the mixing and filling equipment had been rendered inoperable under the watchful eyes of the inspectors, that deployment system could no longer be employed and the Syrian army had lost its means of delivering sarin effectively, even though it still had access to the precursor and other chemicals it would need to make sarin.

The preparations for the transportation of most of the chemical materials of Syria's stockpile out of the country began immediately after the initial inspection campaign was completed, supported by an Operations Planning Group established by the OPCW to coordinate the support of Member States and the Joint Mission (OPCW 2013d) for the removal and destruction operation. This removal and the decision to destroy the chemical weapons materials outside of Syrian territory were two of several modifications to the rules of the CWC that became necessary under the special circumstances of Syria (Trapp 2014a). The sequence of this operation

\footnotetext{
${ }^{5}$ This resolution also removed any possible doubts about the legal power of some of the elements of the Executive Council decision, given the effect of Article 103 of the UN Charter.
} 
followed a simple logic: to prevent any further use of these chemical weapons, one had to immediately disable the system for delivering the chemical agents, then remove as soon as possible all chemical weapons materials that would have required dedicated destruction facilities — which did not exist-from Syrian soil, destroy the remaining material (Isopropanol) in Syria, and then destroy the materials removed from Syria as soon as practicable. At the same time, these measures had to prevent any new production of chemical weapons, and get the weapons, materials and specialized equipment away from anyone who might want to lay their hands on them to use them.

This approach involved adapting some of the legal and regulatory provisions of the Chemical Weapons Convention and its verification procedures to the special situation in Syria (Krutzsch et al. 2014). That in itself was a novelty in the way the OPCW implemented the CWC. States Parties are usually reluctant to change treaty provisions, in particular when it comes to arms control and security agreements. But special circumstances warranted special measures and the political will to tweak the provisions of the treaty and make them work under these unusual conditions did prevail over the usual caution states exercise in treaty interpretation.

Equally important, the elimination of Syria's chemical weapons program under the conditions of an on-going civil war required a high degree of international cooperation and support for what turned into a complex multilateral overland and maritime operation. The removal operation was supported by countries as diverse as Denmark, Norway, the UK, Germany, China, Russia, and the USA, coordinated with the help of the Joint OPCW-UN Mission and special task forces set up for the different aspects of the operation (OPCW 2014a). The Mediterranean Seaport of Latakia was selected as the exit point for removing the weapons materials from Syria. The chemical weapons materials were packed in ISO transport containers and moved by road to Latakia in several shipments, beginning in January 2014. The last shipment arrived in Latakia in June 2014, some six months later than originally planned; but given the circumstances, this was a remarkable achievement.

Upon arrival of each shipment at the port of Latakia, the containers were loaded onto transport ships provided by Denmark and Norway. These transport ships did not permanently dock in Latakia but remained at sea or in Cyprus most of the time, protected by a multilateral contingent of navy ships from a number of countries including China and Russia. Once the removal operation was completed (on June $23,2014)$, the transport ships sailed under escort to the Italian container port of Gioia Tauro where the most dangerous materials (sulfur mustard and DF) were reloaded onto the US maritime vessel Cape Ray. The remaining materials were shipped to facilities in the US, the UK and Finland. The effluents from the destruction aboard the Cape Ray would eventually be shipped to facilities in Germany and Finland for final treatment. 


\section{Chemical Weapons Destruction at Sea}

A critical step was the destruction of the sarin precursor DF and the mustard gas. Well before Syria's accession to the CWC, at the beginning of 2013, the United States had commissioned the development of a field-deployable CW destruction facility that could be airlifted to wherever it was to be deployed, and after a 10-day set-up period could operate independently of any local supplies and destroy chemical agents and precursors by chemical hydrolysis (CBARR 2013). The system was called the "Field Deployable Hydrolysis System" or FDHS. The design capacity of the system would allow it to destroy, under normal operating conditions, the entire Syrian stockpile in approximately 30 days.

The original plan had been to find a country in the neighborhood of Syria that would be willing to host the mobile destruction facility (or to offer one of its destruction facilities if it had one) to destroy the Syrian chemical materials. But a combination of regulatory, political, and technical factors worked against this plan, and no country could be found to take on the destruction task or host the US facility. As time progressed it became clear that a more unconventional approach was needed to eliminate Syria's chemical weapons materials in the agreed timeframe.

In November 2013, it became clear that the only remaining option to eliminate the Syrian CW stockpile outside of Syria would be to destroy the most dangerous chemical materials at sea (OPCW 2013e). The US began to reconfigure its field-deployable hydrolysis facility so it could be set up inside a Navy Reserve container ship, the Cape Ray. A chemical operation that would under normal conditions have been set up on land on an area the size of several football fields now had to be stacked into the three dimensions of a container ship.

The destruction of chemical weapons on a floating platform is not in itself a new concept, but the technical difficulties that needed to be overcome for operating a chemical destruction plant at high sea were nevertheless significant. Here are some of the issues that needed to be considered and resolved before destruction operations could begin in earnest (Trapp 2014b):

- Safety: the need to protect sailors, workers, and OPCW inspectors on board as well as the environment, in case of any spills or accidents, was paramount. Many of the procedures for operating the destruction plant and for responding to incidents needed to be adapted to the compact and at the same time three-dimensional work environment on board the Cape Ray. It also required very careful planning of how the different types of containers had to be loaded, to determine which containers went onto which deck and place within a deck in order to minimize the need to move containers with highly toxic chemicals between or across decks, and to facilitate the way in which the containers' content could be piped to bring the toxic/precursor chemicals and the reaction water and caustics needed for the hydrolysis to the plant, and for back-loading the reaction masses into empty containers. The operation was to be essentially self-contained, that is to say, all chemicals needed for the plant operation were 
on board; no additional materials should be brought on board whilst the facility was in operation; and no reaction masses were to be taken off the ship until the destruction operation was completed.

- The operational environment: normally, a chemical plant operation requires a stable platform to work on, but a ship at sea moves with and within the environment; it was important to establish under which sea condition the facility could be operated safely, and under which it needed to be shut down. Also, the pace with which the facility was being operated needed to be adjusted to the environmental conditions, and operations had to be phased in gradually to make sure the operators had full control over the process and equipment. A significant amount of sea training with the facility operating in simulation mode was undertaken before actual destruction operations could begin.

- Environmental protection: the need to prevent any leaks and accidental releases of the precursor materials and agents as well as of the reaction masses into the environment. This was a particular concern given the vulnerability of the maritime environment in the Mediterranean Sea, and quickly became a political issue in many of the countries with coastlines in the Mediterranean Sea (Walker et al. 2014; Üzümcü 2014).

- Verifiability: despite the unusual environment, the destruction operation had to be undertaken in a way that was consistent with the requirements of the CWC, in particular with regard to the systematic monitoring of all destruction operations by OPCW inspectors to ensure full accountability and to confirm that all chemical weapons materials that had been removed from Syria were in fact destroyed.

Despite these complexities, the destruction at sea proceeded without incidents. It began in late June 2014, and on August 18, 2014, Secretary of State John Kerry confirmed that $100 \%$ of DF (methylphosphonyl difluoride), the precursor for sarin nerve agent, as well as 20 tons of mustard gas had been destroyed aboard the Cape Ray (Kerry 2014). The reaction masses were shipped to facilities in Germany and Finland for final disposal by incineration.

The importance of this collective effort to eliminate the Syrian chemical weapons arsenal cannot be overstated. It was a complex multilateral operation implemented by the OPCW, verified by its inspectors, and supported by financial and in-kind contributions from 21 different countries and the European Union. A total of 10 countries supported the operation with a range of assets and practical support measures, ranging from the delivery of transportation containers to the provision of security and naval support, making available port facilities, and undertaking actual destruction operations of the declared chemical agents and precursors as well as of other chemicals and the reaction masses of the primary destruction operation on board the Cape Ray.

This complex and truly collaborative effort took a stockpile of extremely dangerous and effective chemical weapons out of the context of a horrendous civil war that has in the meantime spread well beyond Syria's borders and become a regional insurgency with global ramifications. Work on completing the destruction of the 
Syrian CW production facilities has yet to be completed but is well under way. The OPCW will continue to verify that the production of chemical weapons in Syria will not be resumed.

\section{New Incidents of Chemical Weapons Uses}

But chemical weapons disarmament cannot remove all toxic chemicals from a country. Many materials that are in daily use in society are poisonous and could be used in improvised chemical weapons. We have today confirmation that improvised chemical weapons in the form of chlorine-filled barrel bombs are being used in Syria (OPCW 2014b). The OPCW has undertaken several fact-finding missions and has on a number of occasions confirmed with a high degree of confidence that chlorine has been employed as a means of war fighting in Syria (OPCW 2015). There is also no doubt that "Daesh" and groups associated with it have shown an interest in acquiring chemical weapons, and reports-yet to be independently verified - suggest that Daesh may have used mustard gas against Kurdish fighters in Iraq (Associated Press 2015).

The OPCW's Executive Council as well as the UN Security Council have condemned the use of chlorine in the Syrian armed conflict, and further investigations are being conducted by the OPCW Fact-Finding Mission and the OPCW-UN Joint Investigation Mechanism to establish what actually happened. Does this imply that, as a consequence of the recent uses of toxic chemicals in the Syrian conflict, the threshold against the use of toxic chemicals in armed conflict has in fact been lowered? Statements by political leaders and international bodies including the Security Council and the OPCW seem to point in the opposite direction; to use Ban Ki Moon's words: "the use of chemical weapons by any side under any circumstances would constitute an outrageous crime with dire consequences, and a crime against humanity" (Ban 2013b). But to prevent a lowering of the threshold for the use of chemical weapons, it will be important to bring those responsible for the use of chemical weapons in Syria to justice.

\section{Attribution and Accountability}

Issues of attribution and accountability were not taken up by the investigations under the UN Secretary-General Mechanism (UN-SGM). Investigating culpability would have required a type of investigation different from what the SGM is: a science-based fact finding mission. This is not to say that science cannot help in identifying the responsible individuals who ordered the use of sarin, but a fact-finding mission conducted at the sites of the alleged chemical weapons use and hosted by the Syrian government differs in certain respects from a criminal investigation. 
There are, however, other international mechanisms such as the Human Rights Council's Independent Commission of Inquiry for Syria or the International Criminal Court (ICC), which could be used to investigate issues related to attribution and accountability. Whilst the Syria Commission has been actively collecting and securing evidence with regard to alleged human rights violations, by all parties involved in the Syrian conflict, the ICC has not been activated. Any use of chemical weapons in armed conflict would fall under its jurisdiction under the Rome Statutes as amended in Cartagena; but as Syria is not a member of the ICC, this would have required an express authorization by the Security Council.

However, the Security Council did not make use of this mechanism but instead decided to establish a separate, dedicated investigation mechanism: a Joint Investigation Mechanism of the UN Secretary-General in close coordination with the OPCW (UN 2015). It is too early to comment on how effective this mechanism will be, but past experience strongly suggests that it will only yield results if the Security Council remains united in its support of the work of the Joint Investigation Mission, and can avoid the politicization of issues related to its mandate, scope and the nature of the investigation.

\section{Conclusions}

Many lessons have been learnt and are still being learnt in the process of eliminating the chemical weapons program of Syria. Some issues that are being pursued already by the United Nations, the OPCW, the WHO, and other relevant actors include:

- Further strengthen the authority and operational capacity of the UN Secretary-General Mechanism to investigate allegations of the use of chemical and biological weapons

- Organize effective interagency cooperation to implement complex and demanding operations in dangerous and potentially hostile environments

- Appreciate the role that disarmament and arms control can play (but also their limitations) in extreme circumstances including during armed conflict

- Preserve and strengthen the ways in which effective multilateral collaboration can be orchestrated despite existing disagreements on a number of key policy and security issues.

\section{References}

Associated Press. 2015. German intelligence confirms Isis used mustard gas in Iraq, says news report. The Guardian, September 8. http://www.theguardian.com/world/2015/sep/08/germanintelligence-confirms-isis-used-mustard-gas-in-iraq-says-news-report. Accessed 27 Oct 2015. 
Ban Ki-moon. 2013a. Secretary-general's press encounter on Syrian government request. New York, March 21. http://www.un.org/sg/offthecuff/index.asp?nid=2745. Accessed 27 Oct 2015.

Ban Ki-moon. 2013b. Secretary-General's remarks to the third review conference of the states parties to the Chemical Weapons Convention. The Hague, April 8, http://www.un.org/sg/ statements/index.asp?nid=6722 . Accessed 27 Oct 2015.

Chemical, Biological, Application and Risk Reduction Business Unit (CBARR). 2013. The field deployable hydrolysis system. CBARR News 1.8 Special Edition. http://www.ecbc.army.mil/ cbarr/newsletter/2013/CBARR_August2013.pdf. Accessed 29 Sept 2016.

France. 2013. Syria/Syrian Chemical Programme-National executive summary of declassified intelligence. Paris, September 3. http://www.diplomatie.gouv.fr/en/IMG/pdf/Syrian Chemical_Programme.pdf . Accessed 27 Oct 2015.

Gladstone, Rick. 2013. Russia says study suggests Syria rebels used sarin. The New York Times, July 9. http://www.nytimes.com/2013/07/10/world/middleeast/russia-says-study-suggestssyria-rebels-used-sarin.html. Accessed 27 Oct 2015.

ICRC. 2005. Customary law. International Review of the Red Cross 87.857, Rule 74.

Kerry, John. 2014. Milestone in Eliminating Syria's Chemical Weapons Programme. Press Statement, August 18. www.state.gov. Accessed 27 Oct 2015.

Krutzsch, Walter, Eric Myjer, and Ralf Trapp. 2014. Part Six. Annex to the commentary: Issues raised by the accession of Syria to the chemical weapons convention. The chemical weapons convention: A commentary, eds. Walter Krutzsch, Eric Myjer, and Ralf Trapp, 689-701. Oxford: Oxford University Press.

MacFarquhar, Neil, and Eric Schmitt. 2012. Syria threatens chemical attack on foreign forces. The New York Times, July 23. http://www.nytimes.com/2012/07/24/world/middleeast/chemicalweapons-wont-be-used-in-rebellion-syria-says.html. Accessed 27 Oct 2015.

OPCW 2013a. Russian Federation and the United States of America. Framework for Elimination of Syrian Chemical Weapons. Executive Council document EC-M-33/Nat.1, September 17.

OPCW 2013b. Destruction of Syrian Chemical Weapons. Executive Council Decision EC-M-33/ Dec.1, September 27. https://www.opcw.org/?id=1902. Accessed 27 Oct 2015.

OPCW 2013c. Progress in the Elimination of the Syrian Chemical Weapons Programme. Note by the Director-General, Executive Council document EC-M-34/DG.01, October 25.

OPCW 2013d. Progress in the Elimination of the Syrian Chemical Weapons Programme. Note by the Director-General, Executive Council document EC-M-35/DG.01, November 25.

OPCW 2013e. Progress in the Elimination of the Syrian Chemical Weapons Programme. Note by the Director-General, Executive Council document EC-M-36/DG.01, December 2.

OPCW 2014a. Progress in the Elimination of the Syrian Chemical Weapons Programme. Note by the Director-General, Executive Council document EC-M-44/DG.02, August 25.

OPCW 2014b. OPCW Fact Finding Mission: "Compelling Confirmation" That Chlorine Gas Used as Weapon in Syria. Press Release, September 10. https://www.opcw.org/news/article/ opcw-fact-finding-mission-compelling-confirmation-that-chlorine-gas-used-as-weapon-insyria/. Accessed 27 Oct 2015.

OPCW 2015. Allegations of Toxic Chemical Attacks in Syria. Press Release, March 25. https:// www.opcw.org/news/article/allegations-of-toxic-chemical-attacks-in-syria/. Accessed 27 Oct 2015.

Robinson, Julian Perry. 2013. Alleged Use of Chemical Weapons in Syria. Harvard Sussex Project Occasional Paper 4. http://www.sussex.ac.uk/Units/spru/hsp/occasional\%20papers/HSPOP_4. pdf. Accessed 29 Sept 2016.

Trapp, Ralf. 2014a. Elimination of the chemical weapons stockpile of Syria. Journal of Conflict and Security Law 19 (1): 7-23.

Trapp, Ralf. 2014b. The Elimination of State Chemical Weapons Programmes: Past Experiences and Current Challenges. Paper presented at the 4th International Conference on Industrial and Hazardous Waste Management, September 2-4. Chania (Crete), Greece.

UNGA. 2013. United Nations General Assembly Document A/HRC/23/58, July 18, 2013. Paragraph 136. https://documents-dds-ny.un.org/doc/UNDOC/GEN/G13/156/20/PDF/G13156 20.pdf?OpenElement. Accessed 27 Oct 2015. 
UN Mission. 2013. United Nations Mission to investigate allegations of the use of chemical weapons in the Syrian Arab Republic. Report on the alleged use of chemical weapons in the Ghouta Area of Damascus on 21 August 2013. http://www.un.org/zh/focus/northafrica/ cwinvestigation.pdf. Accessed 27 Oct 2015.

UNODA. 2013. United Nations Office of Disarmament Affairs. Final Report of the United Nations Mission to investigate allegations of the use of chemical weapons in the Syrian Arab Republic. https://unoda-web.s3.amazonaws.com/wp-content/uploads/2013/12/report.pdf. Accessed 27 Oct 2015.

UN. 2015. Security Council Unanimously Adopts Resolution 2235 (2015), establishing mechanism to identify perpetrators using chemical weapons in Syria. Security Council meetings coverage. http://www.un.org/press/en/2015/sc12001.doc.htm. Accessed 27 Oct 2015.

United States, 2013. U.S. Government Assessment of the Syrian Government's Use of chemical weapons on August 21, 2013. https://www.whitehouse.gov/the-press-office/2013/08/30/ government-assessment-syrian-government-s-use-chemical-weapons-august-21. Accessed 27 Oct 2015.

Üzümcü, Ahmet. 2014. Letter of OPCW Director-General to the Pancretan Commission Against the Destruction of Syrian Chemical Weapons in the Enclosed Sea of the Mediterranean Sea. July 29, 2014. https://www.opcw.org/fileadmin/OPCW/ODG/uzumcu/DG_Letter_Pancretan_ Commission.pdf. Accessed 27 Oct 2015.

Walker, Paul, et al. 2014. Open Letter to Secretaries John Kerry and Chuck Hagel: public outreach and stakeholder involvement in destruction of Syrian chemical weapons. http://www.the-trench. org/open-letter/. Accessed 27 Oct 2015.

Open Access This chapter is licensed under the terms of the Creative Commons Attribution-NonCommercial 2.5 International License (http://creativecommons.org/licenses/by-nc/ $2.5 /$ ), which permits any noncommercial use, sharing, adaptation, distribution and reproduction in any medium or format, as long as you give appropriate credit to the original author(s) and the source, provide a link to the Creative Commons license and indicate if changes were made.

The images or other third party material in this chapter are included in the chapter's Creative Commons license, unless indicated otherwise in a credit line to the material. If material is not included in the chapter's Creative Commons license and your intended use is not permitted by statutory regulation or exceeds the permitted use, you will need to obtain permission directly from the copyright holder.

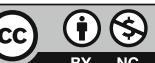

